\title{
Evaluation of some Wheat Genotypes under Water Stress Conditions in Upper Egypt Noreldin, T. ${ }^{1}$ and M. SH. M. Mahmoud ${ }^{2}$ \\ ${ }^{1}$ Water Requirement and Field Irrigation Research Department, Soils, Water and Environment Research Institute, Agriculture Research Center \\ ${ }^{2}$ Wheat Research Department; Field Crops Research Institute, Agriculture Research Center ABSTRACT
}

Response of eighteen Egyptian wheat genotypes to both full irrigation $(100 \% \mathrm{ETc})$ and deficit irrigation $(60 \% \mathrm{ETc})$ were evaluated to identify water stress effects on yield and yield components. The field experiments were conducted in Assuit Research Station, Assuit Governorate, Egypt, during 2013/14 and 2014/15 winter growing seasons. Five stress tolerance indices were assessed, namely Mean Productivity (MP), Geometric Mean Productivity (GMP), Stress Tolerance (TOL), Stress Susceptibility Index (SSI) and Stress Tolerance Index (STI) to evaluate the response of the tested 18 wheat genotypes to imposed water stress. In addition, water productivity (WP), water consumptive use (WCU) and water use efficiency (WUE) for the studied genotypes were considered. The experimental design was stripe block design, where the irrigation treatments were in the main plots and genotypes were allocated in the sub plots. The obtained results indicate that all the evaluated characteristics responded significantly to the adopted irrigation treatments, genotypes and their interactions. The means of all genotypes significantly decreased for most characters in the two growing seasons under deficit irrigation. Based on drought indices MP, GMP, STI, Line 5 was identified as the suitable genotype under water stress conditions due to lower values for TOL and SSI indices. Total applied irrigation amount was $2722 \mathrm{~m} 3 \mathrm{fed}-1$ under full irrigation condition, and $1633 \mathrm{~m} 3 \mathrm{fed}-1$ under stress conditions, and the corresponding WCU values were 2042 and $1225 \mathrm{~m} 3 \mathrm{fed}-1$, respectively. WUE values exhibited a reverse trend, where higher values were recorded for deficit irrigation condition. It is evident that genotype 5 is potentially water use efficient. Furthermore, under full and deficit irrigation, genotype 5 expressed the highest yield and WP surpassing the commercial varieties. So, such genotype is more suitable for full irrigation and water stress conditions compared with other tested genotypes as well as possessing high values for MP, GMP, STI and expressed low values for SSI and TOL indices.

Keywords: Wheat genotypes, Water stress, Drought indices, Water productivity and Water Use Efficiency.

\section{INTRODUCTION}

Efficient water utilization for wheat production is of prime importance in order to reduce the gap between production and consumption and to conserve the available water resources as well. Limited water resources in Egypt are the major factor facing expansion of wheat growing areas. Additionally, climate changes are expected to increase risks of drought. Thus, breeding drought tolerance crops is vital to both mild and severe stress conditions. This implies a need for better characterization of crop biodiversity in order to understand their response to drought, and to develop better information on the physiological mechanisms crucial to increase production (Almeselmani et al., 2015).

Increasing wheat grain yield is correlated to the increase in yield components values, such as number of spikes $\mathrm{m}^{2}$, kernel weight and number of kernels spike1. Number of kernels spike-1 is the most affected yield component with water stress and it has been proposed as an important selection criterion for drought tolerance (Shpiler and Blum 1991). Menshawey et al., (2006) found that number of kernels spike-1 is more drought sensitive compared with number of spikes per square meter. Moreover, Zafarnaderi et al. (2013) reported that path analysis indicated that number of grains spike-1, 1000-grain weight, number of fertile tillers and peduncle length were the most effective components on grain yield. Therefore, these traits could be used as important indices for selecting high yielding bread wheat genotypes. Moisture stress is known to reduce biomass, tillering ability, grains per spike and grain size at any stage when it occurs. So, the overall effect of moisture stress depends on intensity and length of stress (Bukhat, 2005). Water stress imposed during later stages might additionally cause a reduction in number of kernels ear-1 and kernel weight (Gupta et al., 2001).
Moreover, Zareian and Hamidi (2014) reported that water stress through withholding irrigation at the ear emergence and grain filling phases reduced grain yield and its components. Esmail et al., (2016) evaluated 25 bread wheat genotypes under deficit water conditions and they found highly significant differences among the genotypes for all characters indicating the presence of considerable variability among them. Water stress not only affects the morphology but also severely affects the metabolism of the plant. The extent of modification depends upon the cultivar, growth stage, duration and intensity of stress (Mark and Antony 2005).

Selecting wheat cultivars based on their yield performance under drought conditions is a common approach, therefore, some drought stress indices or selection criteria have been suggested by different researches (Talebi et al., 2009 and Pireivatlou et al., 2010). This is because losses of yield are the main concern of plant breeders and they emphasis on yield performance under water stress conditions (Nazari and Pakinyat, 2010). Sio-Semardeh et al., (2006) used drought tolerant indices in wheat and found that under moderate stress, mean productivity (MP), geometric mean productivity (GMP) and stress tolerance index (STI) were more effective in identifying high yielding cultivars in both drought-stressed and irrigated conditions. Under severe stress, none of the indices used were able to identify high yielding cultivars group. Guttieri et al., (2001) used stress susceptibility index (SSI) criterion suggested that SSI value more than 1.0 indicating above-average susceptibility and SSI value less than 1.0 indicated below-average susceptibility to drought stress. Singh et al., (2009) found that, grain yield and yield components of wheat were decreased with decreasing irrigation water amounts. Several studies reported that water use efficiency (WUE) values 
were higher under water deficit than high irrigation condition, especially when irrigation is applied in the critical growth stages of plant (Mandal et al., 2005). Haikel and El-Melegy, (2005) concluded that maximum grain yield and minimum water use efficiency of wheat was recorded by irrigation with recommended requirements under sandy soils conditions and sprinkler irrigation system. Water use efficiency (WUE) generally decreased linearly with increasing seasonal irrigation rates (Wang et al., 2012).

The objective of this study was a field evaluation of eighteen wheat genotypes under full irrigation and water stress to identify high-yielding genotypes under drought stress, with higher water use efficiency in order to utilize the Egypt's limited water resources efficiently.

\section{MATERIALS AND METHODS}

The present investigation was conducted at the experimental farm of Arab El-Awammer, Agriculture Research Center, Assuit Governorate, Egypt (latitude 27, $11^{\prime} \mathrm{N}$ and longitude $31^{\circ}, 06^{\prime} \mathrm{E}$ ), during the two successive winter seasons of 2013/14 and 2014/15. Some chemical and soil - water constants of the experimental soil are presented in Table 1. In addition, soil particle size distribution, hydraulic conductivity, Organic matter and $\mathrm{CaCO} 3$ contents are shown in Table 2. Thirteen genotypes and five wheat cultivars were evaluated to drought tolerance under sprinkler irrigation system in sandy calcareous soil. Table 3 presents pedigree of the thirteen genotypes and five wheat cultivars used in the present study.

Table 1. Some soil chemical properties of the experimental site before cultivation

\begin{tabular}{|c|c|c|c|c|c|c|c|c|c|c|}
\hline \multirow{2}{*}{$\begin{array}{l}\text { Soil depth } \\
\text { (cm) }\end{array}$} & \multirow{2}{*}{ PH } & \multirow{2}{*}{$\begin{array}{c}\text { EC } \\
\text { dSm-1 }\end{array}$} & \multicolumn{4}{|c|}{ Soluble cations (meq L-1) } & \multicolumn{3}{|c|}{ Soluble anions (meq L-1) Available $P$} & \multirow{2}{*}{$\begin{array}{c}\text { Total } \\
\text { nitrogen }(\%) \\
\end{array}$} \\
\hline & & & $\mathbf{C a}++$ & Mg++ & $\mathbf{N a}+$ & $\mathbf{K}+$ & CO3--+HCO3- & Cl- & $(\mathrm{ppm})$ & \\
\hline $00-15$ & 8.1 & 0.42 & 2.2 & 1.4 & 0.29 & 0.96 & 2.25 & 2.60 & 8.32 & 0.005 \\
\hline $15-30$ & 8.5 & 0.39 & 1.5 & 1.5 & 0.19 & 0.95 & 1.90 & 1.80 & 8.32 & 0.004 \\
\hline $30-45$ & 8.6 & 0.26 & 1.1 & 0.89 & 0.14 & 0.61 & 1.42 & 1.20 & 8.30 & 0.002 \\
\hline $45-60$ & 8.3 & 0.24 & 1.0 & 0.82 & 0.13 & 0.47 & 1.15 & 0.90 & 8.28 & 0.001 \\
\hline Mean & 8.4 & 0.33 & 1.4 & 1.16 & 0.19 & 0.75 & 1.68 & 1.5 & 8.31 & 0.003 \\
\hline Soil depth & \multicolumn{10}{|c|}{ Moisture content (Volumetric \%) } \\
\hline$(\mathrm{cm})$ & \multicolumn{3}{|c|}{ Saturation percentage } & \multirow{2}{*}{\multicolumn{3}{|c|}{ Field capacity }} & \multicolumn{2}{|c|}{ Wilting point } & \multicolumn{2}{|c|}{ Available water } \\
\hline $00-15$ & \multirow{2}{*}{\multicolumn{3}{|c|}{25.2}} & & & & & & \multirow{2}{*}{\multicolumn{2}{|c|}{$\begin{array}{l}7.6 \\
5.8\end{array}$}} \\
\hline $15-30$ & \multirow{2}{*}{\multicolumn{3}{|c|}{$\begin{array}{l}23.3 \\
21.7\end{array}$}} & \multicolumn{3}{|c|}{10.0} & \multicolumn{2}{|l|}{42.9} & & \\
\hline $30-45$ & & & & \multicolumn{3}{|c|}{9.50} & \multicolumn{2}{|l|}{4.0} & \multicolumn{2}{|r|}{5.6} \\
\hline $45-60$ & \multicolumn{3}{|c|}{23.0} & \multicolumn{3}{|c|}{11.8} & \multicolumn{2}{|l|}{4.9} & \multicolumn{2}{|r|}{6.9} \\
\hline Mean & \multicolumn{3}{|c|}{23.3} & \multicolumn{3}{|c|}{10.9} & \multicolumn{2}{|l|}{4.5} & \multicolumn{2}{|r|}{6.5} \\
\hline
\end{tabular}

Table 2. Soil particle size distribution, hydraulic conductivity, organic matter and CaCO3 content before cultivation

\begin{tabular}{|c|c|c|c|c|c|c|c|c|}
\hline \multirow{2}{*}{$\begin{array}{l}\text { Soil depth } \\
\text { (cm) }\end{array}$} & \multirow{2}{*}{$\begin{array}{c}\text { Gravely } \\
(\%)\end{array}$} & \multicolumn{3}{|c|}{ Particle size distribution (\%) } & \multirow{2}{*}{$\begin{array}{l}\text { Textural } \\
\text { class }\end{array}$} & \multirow{2}{*}{$\begin{array}{c}\text { Organic } \\
\text { matter }(\%)\end{array}$} & \multirow{2}{*}{$\begin{array}{c}\mathrm{CaCO3} \\
(\%)\end{array}$} & \multirow{2}{*}{$\begin{array}{c}\text { H.C } \\
(\mathrm{cm} / \mathrm{h})\end{array}$} \\
\hline & & Sand & Silt & Clay & & & & \\
\hline $00-15$ & 34.5 & 90.0 & 6.7 & 2.9 & & 0.27 & 32.2 & 71.2 \\
\hline $15-30$ & 30.2 & 90.2 & 6.8 & 3.0 & & 0.21 & 33.8 & 60.4 \\
\hline $30-45$ & 46.6 & 89.4 & 7.4 & 3.2 & Sandy & 0.17 & 25.4 & 46.8 \\
\hline $45-60$ & 46.3 & 89.0 & 7.5 & 3.5 & calcareous & 0.11 & 32.0 & 73.9 \\
\hline Mean & 39.4 & 89.9 & 7.1 & 3.0 & & 0.19 & 30.9 & 63.1 \\
\hline
\end{tabular}

Table 3. Pedigree of the thirteen genotypes used in the study a long with the five commercial cultivars

\begin{tabular}{lllr}
\hline No & Genotypes & Pedigree & Origin \\
\hline 1 & Line1 & Gemmeiza3*HD 2501 & Egypt *India \\
2 & Line2 & Gemmeiza3* HD 2501 & Egypt *India \\
3 & Line3 & Gemmeiza3* HD 2501 & Egypt *India \\
4 & Line4 & Gemmeiza3* HD 2501 & Egypt *India \\
5 & Line5 & Gemmeiza3*HD 2501 & Egypt *India \\
6 & Line6 & Bb/7C*2//Y50E/Kal*3//SKh8/4/Prv/ww/5/3/BJ"S"//on*3/Bon & Egypt \\
7 & Line7 & HD2501 & India \\
8 & Line8 & Vorona/Cno79*Sids 6 & Mexico* Egypt \\
9 & Line9 & Vorona/Cno79*Sids 6 & Mexico* Egypt \\
10 & Line10 & Vorona/Cno79*Sids 6 & Mexico* Egypt \\
11 & Line11 & Vorona/Cno79*Sids 6 & Mexico* Egypt \\
12 & Line12 & Vorona/Cno79*Sids 6 & Mexico* Egypt \\
13 & Line13 & Vorona/Cno79 & Mexico \\
14 & Sids-6 & & Egypt \\
15 & Shandaweel-1 & STTE/MO/4/NAC/TH.AC//3*PVN/3/MIRLO/BUC. & Egypt \\
16 & Sahel-1 & & Egypt \\
17 & Sakha 93 & Sakha92/TR 810328 S8871-1S-2S-1S-0S & Egypt \\
18 & Sids-1 & HD2172/Pavon "S"// 1158.58//Maya 74 “S” Sd 46-4Sd-2Sd-1Sd-0Sd & Egypt \\
\hline
\end{tabular}

Planting dates were on the 29th November and 8th December during 2013/2014 and 2014/2015 growing seasons, respectively. The soil was plowed to provide a satisfactory seed bed for planting. Calcium super phosphate $(15.5 \% \mathrm{P} 2 \mathrm{O} 5)$ was incorporated into the surface soil during land preparation at the rate of $200 \mathrm{~kg}$ fed-1. The plot area was $4.2 \mathrm{~m} 2$ and consisted of six wheat rows $20 \mathrm{~cm}$ in between and $3.5 \mathrm{~m}$ in length. Wheat seeds at the rate of $50 \mathrm{~g}$ plot- 1 were hand drilled.
Nitrogen fertilizer was added at the rate of $120 \mathrm{kgfed}-1$ in the form of ammonium nitrate $(33.5 \% \mathrm{~N})$ at five equal doses after planting. Other cultural practices were done as recommended for wheat production in newly reclaimed land. Number of days to heading and number of days to maturity were calculated during the growing season. Harvesting was done after 148 days and 141 days from sowing in 1st and 2nd growing seasons, respectively. Grain yield and its components namely 
plant height $(\mathrm{cm})$, number of tillers/m2 were recorded and number of kernels spike-1 were estimated as the average of ten spikes taken randomly, 1000-kernel weight $(\mathrm{g})$ was recorded as the average of two random samples of clean grains, biological yield/plot $(\mathrm{kg})$ was estimated as total of above ground plants, and grain yield/plot $(\mathrm{kg})$ was estimated. Both biological and grain yields were converted into ton fed-1.

Evapotranspiration (ETo) as estimated by CropWat model (Smith, 1991) and weather data for the experimental site during the two growing seasons are presented in Table 4.

Table 4. Monthly average of meteorological data during 2013/2014 and 2014/2015 winter growing seasons

\begin{tabular}{|c|c|c|c|c|c|c|}
\hline \multirow{2}{*}{ Month } & \multicolumn{2}{|c|}{ Temperature (oC) } & \multirow{2}{*}{$\begin{array}{c}\text { Relative humidity } \\
\text { (\%) }\end{array}$} & \multirow{2}{*}{$\begin{array}{l}\text { Wind speed } \\
\text { (kmday-1) }\end{array}$} & \multirow{2}{*}{$\begin{array}{l}\text { Sunshine } \\
\text { (hours) }\end{array}$} & \multirow{2}{*}{ ETo $(\mathrm{mm})$} \\
\hline & Max. & Min. & & & & \\
\hline \multicolumn{7}{|c|}{$2013 / 2014$} \\
\hline November & 27.5 & 12.1 & 49.3 & 208.8 & 9.4 & 4.1 \\
\hline December & 23.2 & 8.10 & 52.3 & 254.4 & 9.0 & 3.6 \\
\hline January & 22.0 & 6.20 & 47.5 & 211.2 & 8.9 & 3.3 \\
\hline February & 23.6 & 7.10 & 37.5 & 259.2 & 9.7 & 4.6 \\
\hline March & 25.0 & 9.20 & 37.2 & 362.4 & 9.9 & 6.0 \\
\hline April & 32.1 & 15.5 & 30.5 & 343.2 & 10.3 & 6.5 \\
\hline \multicolumn{7}{|c|}{$2014 / 2015$} \\
\hline December & 23.2 & 7.90 & 54.9 & 208.0 & 9.0 & 3.2 \\
\hline January & 24.0 & 7.70 & 49.4 & 255.4 & 8.9 & 3.8 \\
\hline February & 26.9 & 10.5 & 39.6 & 318.0 & 9.7 & 5.5 \\
\hline March & 29.4 & 13.3 & 40.0 & 358.0 & 9.9 & 6.7 \\
\hline April & 32.8 & 16.5 & 32.0 & 296.0 & 10.3 & 7.9 \\
\hline
\end{tabular}

The sprinkler irrigation system was fixed in square spacing pattern $(12 \mathrm{~m} \times 12 \mathrm{~m})$. The rotating sprinkler height was $1.0 \mathrm{~m}$ above the ground with flow rate of 1.2-1.4 $\mathrm{m} 3 /$ hour at 2-3 bars. The adopted irrigation treatments were:

full irrigation $(\mathrm{FI})=\mathbf{1 0 0} \% \mathrm{ETc} \quad$ and

deficit irrigation (DI) $=60 \% \mathrm{ETc}$

The treatments were assessed in Strip Block Design with three replicates. The actual crop evapotranspiration (ETc) was estimated as follows:

ETc $=$ Kc x ETo where:

$\mathrm{ETc}=$ actual crop evapotranspiration rate

$\mathrm{Kc}=$ crop coefficient

$\mathrm{ETo}=$ evapotranspiration rate for a grass reference crop The used Kc values were 0.35, 0.75, 1.13 and 0.75 for initial, crop development, mid- season and lateseason growth stages, respectively, (FAO 1984). The amounts of actual applied irrigation water requirement under each irrigation treatment were determined according to James (1988) using the following equation:

$$
I . R a=\frac{E T c+L f}{E r}
$$

Where:

$\mathrm{I} . \mathrm{Ra}=$ Total irrigation water applied in 3- days interval, $\mathrm{mm}$ $\mathrm{ETc}=$ Actual evapotranspiration, $\mathrm{mm}$

Lf $=$ leaching factor $10 \%$

$\mathrm{Er}=$ irrigation system efficiency $(86 \%)$.

\section{Drought indices}

The Drought tolerance indices vis. Mean Productivity, Geometric Mean Productivity, Stress Tolerance, Stress Susceptibility Index and Stress Tolerance Index were considered in the present investigation in order to verify the performance of the assessed wheat genotypes under the tested DI irrigation regime. Drought tolerance indices were calculated by the following formulae (Table 5).

\section{Table 5. Drought tolerance indices}

\begin{tabular}{|c|c|c|}
\hline Index & Formula* & Reference \\
\hline Mean Productivity & $\mathrm{MP}=(\mathrm{Yp}+\mathrm{Ys}) / 2$ & Hossain et al (1990) \\
\hline Geometric Mean Productivity & $\mathrm{GMP}=(\mathrm{Yp} \times \mathrm{Ys}) 0.5$ & Fernandez (1992) \\
\hline Stress Tolerance & $\mathrm{TOL}=\mathrm{Yp}-\mathrm{Ys}$ & Hossain et al (1990) \\
\hline Stress Susceptibility Index & $\mathrm{SSI}=[1-(\mathrm{Ys} / \mathrm{Yp})] /[1-(\overline{\mathrm{Y}} \mathrm{s} / \overline{\mathrm{Y}} \mathrm{p})]$ & Fischer and Maurer (1978) \\
\hline Stress Tolerance Index & $\mathrm{STI}=(\mathrm{Yp}+\mathrm{Ys}) /(\overline{\mathrm{Y}} \mathrm{p}) 2$ & Fernandez (1992) \\
\hline
\end{tabular}

\section{Crop-water relations}

Water productivity (WP)

Water productivity was estimated as crop yield per cubic meter of applied water according to (Ali et al. 2007) as follows:

\section{Where:}

$$
\mathbf{W P}=\mathbf{G Y} / \mathbf{A W}
$$

$\mathrm{WP}=$ water productivity $(\mathrm{kg}$ grains $\mathrm{m}-3)$;

$\mathrm{GY}=$ grain yield $($ kgfed-1) $\quad \ldots . \quad$ and

$\mathrm{AW}=$ applied water throughout the growing season (m3fed-1).

\section{Water use efficiency (WUE)}

Water Use Efficiency (WUE) of Grain yields (WUEGY) was calculated as outlined by Hamed et al., (2015) as follows:

Where:

\section{WUE $=$ GY $/$ WC}

WUE is the water use efficiency ( $\mathrm{kg} \mathrm{m}-3)$, GY is the grain yield (kgfed-1) and WC is the total water consumption over the whole growing season (m3fed-1).

Water consumptive use efficiency (ECU \%)

The consumptive use efficiency (Ecu) was calculated as described by Doornbos and Pruit (1975) as follows: 


\section{$E C U=(E T c / W a) \times 100$}

Where:

$\mathrm{Ecu}=$ Consumptive use efficiency $(\%)$

$\mathrm{ETc}=$ Total evapotranspiration' consumptive use (m3fed-1)

$\mathrm{Wa}=$ Seasonal water applied (m3fed-1).

Statistical analysis

All data were statistically analyzed according to the technique of analysis of variance (ANOVA) procedures for strip-plot design as published by Gomez and Gomez (1984). Means of the treatment were compared by the least significant difference (LSD) at $5 \%$ level of significance as developed by Waller and Duncan (1969).

\section{RESULTS AND DISCUSSION}

\section{1-Analysis of variance}

The combined analysis of variance in Table 6 revealed highly significant differences between genotypes, under irrigation treatments, and years for all studied traits. This suggests the importance of the assessment of genotypes under deficit irrigation in order to identify the best genetic makeup under deficit irrigation. Similar results were obtained by Tawfelis (2006). The mean square of irrigation treatments explained most of the total variations for all characters in both growing season. Significant variations were detected due to interactions between genotypes and irrigation treatments for all characters. The variations due to genotypes were higher than those of interactions between genotypes and irrigation treatments. The significance of genotypes' variance for all characters under all conditions reflects the presence of sufficient genetic variability between these genotypes and provides the basis for genetic gain (Rajaram et al., 1994). Moreover, the significance of the interactions is a result of the different abilities of genotypes to adjust their characters to the irrigation regime and seasons, suggesting the importance of genotypes assessment under different irrigation treatments to identify the best ones for deficit irrigation.

Table 6. Means squares of the combined analysis of variance for the studied characters over all irrigation treatments and genotypes

\begin{tabular}{lcccccccc}
\hline S.O.V & D.F & $\begin{array}{c}\text { Days to } \\
\text { heading }\end{array}$ & $\begin{array}{c}\text { Days to } \\
\text { maturity }\end{array}$ & $\begin{array}{c}\text { Plant height } \\
\text { (cm) }\end{array}$ & $\begin{array}{c}\text { plants } \\
\text { No m-2 }\end{array}$ & $\begin{array}{c}\text { spikes } \\
\text { No m-2 }\end{array}$ & $\begin{array}{c}\text { 1000-Kernel Biological yield Grain yield } \\
\text { weight (g) } \\
\text { (tonfed-1) }\end{array}$ \\
\hline (tonfed-1)
\end{tabular}

$\mathbf{G}=$ Genotypes; $\mathbf{I}=$ irrigation treatments; $Y=$ year; $N S=$ Non- significant, $*=$ significant and $* *=$ highly significant at 0.05 and 0.01 levels of probability respectively.

\section{2-Mean performance}

Data in Table 7 illustrate that the means of all wheat genotypes were decreased significantly under DI for all studied characters in the two seasons. Line4 and Line6 exhibited the earliest genotypes for days to heading, which comprised 80 and 80 days under FI, respectively, in 1st season and 71 and 71 days in 2 nd season. Under DI, the same lines (Line4 and Line6) still exhibited the earliest values of days to heading e.g. 76 and 74 days in 1st season, and 73 and 71 days in 2 nd season, respectively. Additionally, Line4 and Line6 possessed the shortest days to maturity values under either FI or DI in 1st and 2nd seasons. Days to maturity under FI were 125 and 126 days for Line 4 and Line 6 in 1st season and 103 and 103 days in 2nd season. The corresponding days to maturity under DI were 126 and 126 days in 1st season and 107 and 105 days in 2season, respectively, in the same order of wheat lines. The genotypes Line5, Shandaweel-1 were the latest genotypes for days to heading, with values reached to 96 and 97 days under FI in 1st season and 83 and 87 days in 2nd season. With DI, line11 exhibited the longest value of days to heading e.g.94 days in 1st season, 83 days in 2 nd season.

Respecting days to maturity trait, Line5 still exhibiting higher values under FI amounted to140 and 114 days, respectively, in 1 st and 2 nd seasons. Under DI, Line13 possessed higher days to maturity value (129 days) in 1st season, whereas both Shandaweel-1 and Sahel-1 genotypes exhibited higher values (115 and 115 days) in 2nd season, respectively. These findings could be used as a source of earliness in breeding program. Data in Table 7 indicate significant differences among genotypes for plant height and numbers of tillersm-2. Under FI, Line 11 exhibited the highest value of plant height reached to $93 \mathrm{~cm}$ in 1st season, whereas Line8 and Line11 possessed higher values comprised 75 and $75 \mathrm{~cm}$ in 2nd season. Sakha93 and Sids-1 genotypes possessed lower plant height values under FI in 1st season amounted to 60 and $65 \mathrm{~cm}$, respectively. In 2nd season, Shandaweel-1 genotype possessed the lowest value of plant height that comprised $55 \mathrm{~cm}$. Under DI, the highest plant height value i.e. $82 \mathrm{~cm}$ was recorded for Shandaweel-1 in 1st season, whereas in 2nd season the highest value $(67 \mathrm{~cm})$ was recorded for Line11 genotype. Regarding tillers No m-2 trait, under FI higher values e.g. 217 and 317 were attained by Line5 and Line6 in 1st and 2nd seasons, respectively. Under DI higher tillers No m-2 values i.e. 186 and 275 were observed with Line2 and Line3, respectively, in 1st and 2nd seasons. In this sense, Esmail et al., (2016) evaluated 25 bread wheat genotypes under deficit water conditions and found highly significant differences among the genotypes for all characters indicating presence of considerable variability among them. 
Table 7. Effect of full and deficit irrigation on days to heading and days to maturity, plant height and number of tillers $\mathbf{m}$-2of wheat genotypes in both growing seasons

\begin{tabular}{|c|c|c|c|c|c|c|c|c|c|c|c|c|c|c|c|c|}
\hline \multirow{3}{*}{ Genotypes } & \multicolumn{4}{|c|}{ Days to heading } & \multicolumn{4}{|c|}{ Days to maturity } & \multicolumn{4}{|c|}{ Plant height $(\mathrm{cm})$} & \multicolumn{4}{|c|}{ tillers No m-2 } \\
\hline & \multicolumn{2}{|c|}{ 1st season } & \multicolumn{2}{|c|}{ 2nd season } & \multicolumn{2}{|c|}{ 1st season } & \multicolumn{2}{|c|}{ 2nd season } & \multicolumn{4}{|c|}{ 1st season 2 nd season } & \multicolumn{2}{|c|}{ 1st season } & \multicolumn{2}{|c|}{ 2nd season } \\
\hline & FI & DI & FI & DI & FI & DI & FI & DI & FI & DI & FI & DI & FI & DI & FI & DI \\
\hline Line1 & 94 & 86 & 83 & 81 & 136 & 128 & 114 & 112 & 90 & 80 & 72 & 57 & 200 & 174 & 294 & 226 \\
\hline Line 2 & 92 & 85 & 81 & 77 & 133 & 125 & 111 & 113 & 85 & 58 & 60 & 58 & 211 & 186 & 297 & 264 \\
\hline Line 3 & 94 & 89 & 79 & 73 & 129 & 128 & 113 & 111 & 87 & 70 & 68 & 55 & 150 & 155 & 292 & 275 \\
\hline Line 4 & 80 & 76 & 71 & 73 & 125 & 126 & 103 & 107 & 90 & 67 & 65 & 60 & 184 & 146 & 288 & 213 \\
\hline Line 5 & 96 & 89 & 83 & 81 & 140 & 134 & 114 & 116 & 77 & 70 & 68 & 62 & 217 & 178 & 220 & 240 \\
\hline Line 6 & 80 & 74 & 71 & 71 & 126 & 126 & 103 & 105 & 93 & 75 & 58 & 63 & 213 & 109 & 317 & 199 \\
\hline Line 7 & 82 & 77 & 75 & 70 & 127 & 126 & 105 & 102 & 83 & 63 & 63 & 60 & 214 & 151 & 288 & 237 \\
\hline Line 8 & 82 & 85 & 79 & 82 & 128 & 128 & 114 & 111 & 92 & 68 & 75 & 55 & 191 & 136 & 249 & 263 \\
\hline Line 9 & 88 & 75 & 75 & 74 & 131 & 122 & 108 & 111 & 85 & 67 & 65 & 58 & 204 & 134 & 293 & 244 \\
\hline Line10 & 84 & 81 & 78 & 79 & 134 & 126 & 111 & 113 & 88 & 75 & 70 & 63 & 190 & 112 & 236 & 192 \\
\hline Line 11 & 91 & 94 & 81 & 83 & 135 & 134 & 112 & 113 & 97 & 78 & 75 & 67 & 193 & 137 & 253 & 222 \\
\hline Line 12 & 85 & 75 & 79 & 78 & 127 & 127 & 110 & 114 & 85 & 75 & 72 & 62 & 162 & 149 & 249 & 207 \\
\hline Line 13 & 88 & 82 & 82 & 83 & 130 & 129 & 112 & 113 & 87 & 68 & 78 & 63 & 150 & 146 & 280 & 185 \\
\hline Sids-6 & 86 & 79 & 84 & 84 & 130 & 127 & 112 & 114 & 90 & 78 & 73 & 58 & 186 & 133 & 244 & 189 \\
\hline Shandaweel-1 & 97 & 90 & 87 & 86 & 132 & 128 & 114 & 115 & 82 & 82 & 55 & 53 & 212 & 161 & 287 & 243 \\
\hline Sahel-1 & 96 & 90 & 82 & 82 & 137 & 130 & 111 & 115 & 82 & 75 & 68 & 60 & 174 & 111 & 273 & 188 \\
\hline Sakha93 & 92 & 88 & 77 & 77 & 131 & 129 & 108 & 112 & 70 & 60 & 58 & 52 & 214 & 153 & 213 & 197 \\
\hline Sids-1 & 92 & 86 & 80 & 80 & 135 & 126 & 112 & 114 & 78 & 65 & 67 & 60 & 210 & 118 & 228 & 191 \\
\hline Mean & 89 & 83 & 79 & 79 & 131 & 128 & 110 & 112 & 86 & 71 & 67 & 59 & 193 & 144 & 267 & 221 \\
\hline \multicolumn{17}{|c|}{ F test } \\
\hline$\overline{C . V \%}$ & \multicolumn{4}{|c|}{3.9} & \multirow{2}{*}{\multicolumn{4}{|c|}{$\begin{array}{l}2.5 \\
* * *\end{array}$}} & \multicolumn{4}{|c|}{7.9} & \multicolumn{4}{|c|}{7.8} \\
\hline A & \multirow{2}{*}{\multicolumn{4}{|c|}{$\begin{array}{l}* * * \\
* * *\end{array}$}} & & & & & \multicolumn{4}{|c|}{$* * *$} & \multicolumn{4}{|c|}{$* * *$} \\
\hline B & & & & & \multicolumn{4}{|c|}{$\begin{array}{l}* * * \\
* * *\end{array}$} & \multicolumn{4}{|c|}{$* * *$} & \multicolumn{4}{|c|}{$* * *$} \\
\hline$A \times B$ & & \multicolumn{3}{|c|}{$* * *$} & \multicolumn{4}{|c|}{$\begin{array}{l}* * * \\
\text { NS }\end{array}$} & & & $*$ & & & & & \\
\hline $\mathrm{C}$ & & & & & & & $* * *$ & & & & $* * *$ & & & & & \\
\hline$A \times C$ & & & & & & & $* * *$ & & & & $* * *$ & & & & & \\
\hline $\mathrm{B} \times \mathrm{C}$ & & & & & & & $* * *$ & & & & $* * *$ & & & & & \\
\hline $\mathrm{Ax} B \times \mathrm{C}$ & & & & & & & NS & & & & NS & & & & $*$ & \\
\hline
\end{tabular}

Genotypes (A); Irrigation treatments (B); Year (C); full irrigation (FI); deficit irrigation(DI)

Data in Table 8 Show significant increase in kernel No spikes-1 under full irrigation compared with deficit irrigation. It is worth to indicate that genotype Sids- 6 surpassed the control checks, and exhibited the highest values of kernel No spikes-1 under FI reached to 73 and 59, respectively, in 1 st and 2nd seasons. Under DI the highest kernel No spikes-1 e.g. 64 and 50 were recorded for Line10 and Line2, respectively, in 1st and 2nd seasons. These results agreed with the findings of Zhong-hu and Rajaram (1994), who found that kernel No spikes-1 is more drought sensitive trait compared with number of spike $\mathrm{m}-2$.

Regarding 1000-kernel weight, the adopted irrigation treatments had significant effects on this character in both seasons (Table 8). Generally, 1000kernel weight was adversely affected under deficit irrigation, where the highest 1000 -kernel weight i.e. 44.3 and $43.1 \mathrm{~g}$ were found for line 10 and line 3 under FI, respectively, in 1st and 2nd seasons. Under deficit irrigation Line 3 and Line6 exhibited higher values of 1000-kernel weight comprised 41.9 and $34.6 \mathrm{~g}$, respectively, in 1st 2 nd seasons. The notable decreases in 1000-kernel weight under deficit irrigation for all wheat genotypes under study may be due to male sterility caused by drought stress (Saini and Aspinal 1981). The interaction effect between genotypes and irrigation treatments on 1000- kernel weight was highly significant in both growing season. Table 8 show that Line10 genotype exhibited good performance in 1000kernel weight under both full irrigation (44.3 and 41.7 g) and deficit irrigation (35.7 and $32.5 \mathrm{~g}$ ) in both growing seasons, respectively, which can be used as a source for breeding objectives.

Line1 exhibited higher biological yield values either with FI or DI, where under FI the values were 4.11 and 2.21 ton fed- 1 and reached to 3.45 and 1.59 ton fed-1 under DI, respectively, in 1st and 2nd seasons. As for grain yield under FI, data reveal that the highest figures e.g. 2.75 and 0.60 ton fed-1 resulted from Line13 and line11, respectively, in 1st and 2nd seasons. Line5 exhibited the highest value of grain yield amounted to 2.44 ton fed-1 in 1st season, whereas in 2nd season, the highest value i.e. 0.48 tonfed-1 was recorded for Line10 genotype.

It is clear that values of grain yield in 1st season were higher than those obtained in 2nd one, and such finding was true under full and deficit irrigation treatments. The increases in grain yield in 1st season under FI and DI, over the genotypes average, were 180 and $75 \%$, respectively, comparable with those recorded in 2 nd season. Such grain yield reduction in 2 nd season could be attributed to late sowing date. In addition, higher temperature and wind speed values which were prevailing in January through April (Table 4) might be responsible for reducing the grain yield. In this sense, Ahmed et al., (1994) stated that high temperature in the post an-thesis period of late sown wheat shortened the grain filling period resulting in a smaller endosperm and lower grain weight. Additionally, Singh and Dhaliwal (2000) reported that high temperature and desiccating winds might cause forced maturity of late sown wheat, thus resulting in reduction of test weight. 
Table 8. Effect of full and deficit irrigation on kernels No spikes-1, 1000-kernel weight, biological and grain yields in the two g rowing seasons

\begin{tabular}{|c|c|c|c|c|c|c|c|c|c|c|c|c|c|c|c|c|}
\hline \multirow{3}{*}{ Genotypes } & \multicolumn{4}{|c|}{ Kernels No spikes-1 } & \multicolumn{4}{|c|}{ 1000-kernel weight (g) } & \multicolumn{4}{|c|}{ Biological yield (tonfed-1) } & \multicolumn{4}{|c|}{ Grain yield (tonfed-1) } \\
\hline & \multicolumn{2}{|c|}{ 1st season } & \multicolumn{2}{|c|}{ 2nd season } & \multicolumn{2}{|c|}{ 1st season } & \multicolumn{2}{|c|}{ 2nd season } & \multicolumn{2}{|c|}{ 1st season } & \multicolumn{2}{|c|}{ 2nd season } & \multicolumn{2}{|c|}{ 1st season } & \multicolumn{2}{|c|}{ 2nd season } \\
\hline & FI & DI & FI & DI & FI & DI & FI & DI & FI & DI & FI & DI & FI & DI & FI & DI \\
\hline Line1 & 53 & 36 & 45 & 44 & 40.9 & 39.3 & 38.4 & 33.7 & 4.11 & 3.45 & 2.21 & 1.59 & 2.07 & 1.96 & 0.45 & 0.41 \\
\hline Line 2 & 36 & 36 & 50 & 50 & 44.2 & 41.4 & 34.0 & 25.7 & 3.41 & 2.80 & 1.80 & 0.99 & 2.12 & 2.10 & 0.46 & 0.38 \\
\hline Line 3 & 65 & 45 & 44 & 43 & 42.5 & 41.9 & 37.1 & 31.4 & 2.84 & 2.23 & 1.23 & 0.65 & 1.91 & 1.84 & 0.45 & 0.39 \\
\hline Line 4 & 42 & 32 & 53 & 44 & 42.7 & 35.4 & 33.6 & 31.6 & 3.17 & 2.21 & 1.39 & 0.75 & 2.43 & 1.83 & 0.56 & 0.40 \\
\hline Line 5 & 53 & 50 & 50 & 42 & 41.9 & 32.5 & 31.3 & 30.4 & 3.17 & 2.33 & 1.08 & 0.73 & 2.62 & 2.44 & 0.56 & 0.46 \\
\hline Line 6 & 34 & 26 & 58 & 35 & 37.3 & 33.2 & 35.6 & 34.6 & 2.43 & 1.77 & 1.16 & 0.61 & 1.87 & 1.54 & 0.37 & 0.37 \\
\hline Line 7 & 56 & 58 & 45 & 39 & 42.5 & 40.9 & 33.7 & 30.9 & 3.08 & 1.77 & 1.46 & 0.73 & 2.57 & 1.80 & 0.46 & 0.37 \\
\hline Line 8 & 54 & 33 & 46 & 44 & 41.8 & 40.6 & 43.1 & 30.9 & 3.92 & 1.40 & 1.40 & 0.56 & 2.24 & 1.79 & 0.56 & 0.41 \\
\hline Line 9 & 41 & 36 & 56 & 42 & 38.0 & 35.6 & 32.7 & 28.8 & 2.89 & 1.59 & 1.34 & 0.56 & 2.15 & 2.12 & 0.55 & 0.27 \\
\hline Line 10 & 71 & 64 & 50 & 41 & 44.3 & 41.7 & 35.7 & 32.5 & 3.92 & 1.77 & 1.92 & 0.61 & 2.10 & 2.01 & 0.51 & 0.48 \\
\hline Line 11 & 70 & 36 & 48 & 47 & 41.3 & 36.7 & 35.5 & 29.3 & 3.27 & 1.60 & 1.79 & 0.70 & 2.43 & 2.38 & 0.60 & 0.41 \\
\hline Line 12 & 57 & 28 & 44 & 43 & 42.1 & 40.9 & 32.7 & 30.8 & 2.43 & 1.87 & 0.96 & 0.54 & 2.41 & 2.29 & 0.51 & 0.34 \\
\hline Line 13 & 51 & 40 & 49 & 47 & 40.9 & 40.8 & 36.3 & 33.7 & 2.80 & 2.07 & 1.40 & 0.45 & 2.75 & 2.12 & 0.47 & 0.39 \\
\hline Sids-6 & 73 & 44 & 59 & 40 & 43.9 & 34.6 & 30.9 & 24.7 & 2.43 & 1.63 & 1.23 & 0.55 & 2.40 & 1.96 & 0.46 & 0.29 \\
\hline Shandaweel-1 & 59 & 44 & 50 & 40 & 32.0 & 28.7 & 34.5 & 28.0 & 3.55 & 2.99 & 1.17 & 1.13 & 2.17 & 1.68 & 0.42 & 0.37 \\
\hline Sahel-1 & 43 & 38 & 42 & 38 & 32.8 & 29.8 & 31.0 & 29.7 & 2.43 & 1.67 & 1.25 & 0.51 & 1.73 & 1.54 & 0.42 & 0.35 \\
\hline Sakha93 & 36 & 38 & 41 & 32 & 41.1 & 34.9 & 35.2 & 33.2 & 3.17 & 1.31 & 1.39 & 0.56 & 1.82 & 1.73 & 0.50 & 0.35 \\
\hline Sids-1 & 34 & 25 & 48 & 47 & 42.3 & 29.1 & 32.4 & 29.6 & 2.89 & 1.21 & 1.12 & 0.45 & 2.29 & 2.10 & 0.48 & 0.29 \\
\hline Mean & 49 & 42 & 47 & 44 & 39.2 & 38.0 & 32.7 & 32.4 & 3.00 & 2.100 & 2.20 & $2 . .00$ & 1.40 & 0.70 & 0.50 & 0.40 \\
\hline \multicolumn{17}{|c|}{ F test } \\
\hline C.V\% & \multirow{2}{*}{\multicolumn{4}{|c|}{$\begin{array}{r}8.7 \\
* * *\end{array}$}} & \multirow{2}{*}{\multicolumn{4}{|c|}{$\begin{array}{l}8.1 \\
* * *\end{array}$}} & \multirow{2}{*}{\multicolumn{4}{|c|}{20.7}} & \multirow{2}{*}{\multicolumn{4}{|c|}{14.4}} \\
\hline A & & & & & & & & & & & & & & & & \\
\hline B & \multicolumn{4}{|c|}{$* * *$} & \multicolumn{4}{|c|}{ NS } & \multicolumn{4}{|c|}{$* * *$} & \multicolumn{4}{|c|}{$* * *$} \\
\hline AXB & \multicolumn{4}{|c|}{$* * *$} & \multicolumn{4}{|c|}{$* * *$} & \multicolumn{4}{|c|}{$* * *$} & & & & \\
\hline $\mathrm{C}$ & & & & & & & & & & & $* *$ & & & & & \\
\hline $\mathrm{AXC}$ & & & & & & & & & & & $* *$ & & & & & \\
\hline BXC & & & & & & & & & & & $* *$ & & & & & \\
\hline AXBXC & & & & & & & & & & & $*$ & & & & & \\
\hline
\end{tabular}

Genotypes (A); Irrigation treatments (B); Year (C); full irrigation (FI); deficit irrigation (DI).

\section{3-Drought indices}

Data in Table 9 reveal that the highest value of mean productivity (MP) was found with Line 5 genotype which had the highest yield under both normal and stress conditions, whereas the lowest value of MP (1.64) was recorded for Sahel-1 in 1st season and for Sids-6 in 2nd season that comprised 0.37. Even though for identification of high yielding and drought tolerant lines, the MP index was more favorable as reported by Ahmadzadeh (1990). However, Shirazi et al. (2009) stated that high yield in non-stress condition led the MP index to increase and cannot be a valid indicator to identify the tolerant genotypes. Regarding to GMP, similar trend to that of MP was indicated, where the highest value of GMP was recorded for Line 5 genotype, which reached to 2.53 and 0.51 in 1 st and 2 nd seasons, respectively. Sahel-1 genotype in 1st season, and both Sids-1, Sids-6 and Line 6 genotypes in 2nd season exhibited lower values of GMP, which comprised $0.37,0.37$ and 0.37 , respectively.

Table 9. Drought tolerance indices of 18 wheat genotypes based on grain yield

\begin{tabular}{|c|c|c|c|c|c|c|c|c|c|c|c|c|c|c|}
\hline \multirow{3}{*}{ Genotypes (G) } & \multicolumn{14}{|c|}{ Grain yield (tonfed-1) } \\
\hline & \multicolumn{7}{|c|}{ 1st season } & \multicolumn{7}{|c|}{ 2nd season } \\
\hline & $(\mathbf{Y p})$ & (Ys) & $\mathbf{M P}$ & GMP & TOL & SSI & STI & (Yp) & (Ys) & MP & GMP & TOL & SSI & STI \\
\hline Line1 & 2.07 & 1.96 & 2.02 & 2.01 & 0.11 & 0.44 & 0.81 & 0.45 & 0.41 & 0.43 & 0.43 & 0.04 & 0.36 & 3.58 \\
\hline Line 2 & 2.12 & 2.1 & 2.11 & 2.11 & 0.02 & 0.08 & 0.85 & 0.46 & 0.38 & 0.42 & 0.42 & 0.08 & 0.71 & 3.50 \\
\hline Line 3 & 1.91 & 1.84 & 1.88 & 1.87 & 0.07 & 0.30 & 0.76 & 0.45 & 0.39 & 0.42 & 0.42 & 0.06 & 0.54 & 3.50 \\
\hline Line 4 & 2.43 & 1.83 & 2.13 & 2.11 & 0.60 & 2.04 & 0.86 & 0.56 & 0.40 & 0.48 & 0.47 & 0.16 & 1.17 & 4.00 \\
\hline Line 5 & 2.62 & 2.44 & 2.53 & 2.53 & 0.18 & 0.57 & 1.02 & 0.56 & 0.46 & 0.51 & 0.51 & 0.10 & 0.73 & 4.25 \\
\hline Line 6 & 1.87 & 1.54 & 1.71 & 1.70 & 0.33 & 1.46 & 0.69 & 0.37 & 0.37 & 0.37 & 0.37 & 0.00 & 0.00 & 3.08 \\
\hline Line 7 & 2.57 & 1.80 & 2.19 & 2.15 & 0.77 & 2.48 & 0.88 & 0.46 & 0.37 & 0.42 & 0.41 & 0.09 & 0.80 & 3.46 \\
\hline Lin & 2.24 & 1.79 & 2.02 & 2.00 & 0.45 & 1.66 & 0.81 & 0.56 & 0.41 & 0.49 & 0.48 & 0.15 & 1.09 & 4.04 \\
\hline Line & 2.15 & 2.12 & 2.14 & 2.13 & 0.03 & 0.12 & 0.86 & 0.55 & 0.27 & 0.41 & 0.39 & 0.28 & 2.08 & 3.42 \\
\hline & 2.1 & 2.01 & 2.06 & 2.05 & 0.09 & 0.35 & 0.83 & 0.51 & 0.48 & 0.50 & 0.49 & 0.03 & 0.24 & 4.12 \\
\hline 11 & 2.43 & 2.38 & 2.41 & 2.40 & 0.05 & 0.17 & 0.97 & 0.60 & 0.41 & 0.51 & 0.50 & 0.19 & 1.29 & 4.21 \\
\hline & 2.41 & 2.29 & 2.35 & 2.35 & 0.12 & 0.41 & 0.95 & 0.51 & 0.34 & 0.43 & 0.42 & 0.17 & 1.36 & 3.54 \\
\hline 13 & 2.75 & 2.12 & 2.44 & 2.41 & 0.63 & 1.89 & 0.98 & 0.47 & 0.39 & 0.43 & 0.43 & 0.08 & 0.70 & 3.58 \\
\hline & 24 & 1.96 & 2.18 & 2.17 & 0.44 & 1.52 & 0.87 & 0.46 & 0.29 & 0.38 & 0.37 & 0.17 & 1.51 & 3.12 \\
\hline indawe & 2.17 & 1.68 & 1.93 & 1.91 & 0.49 & 1.87 & 0.78 & 0.42 & 0.37 & 0.40 & 0.39 & 0.05 & 0.49 & 3.29 \\
\hline & 173 & 1.54 & 1.64 & 1.63 & 0.19 & 0.91 & 0.66 & 0.42 & 0.35 & 0.39 & 0.38 & 0.07 & 0.68 & 3.21 \\
\hline ha93 & 1.82 & 1.73 & 1.78 & 1.77 & 0.09 & 0.41 & 0.72 & 0.50 & 0.35 & 0.43 & 0.42 & 0.15 & 1.23 & 3.54 \\
\hline & 2.29 & 2.1 & 2.20 & 2.19 & 0.19 & 0.69 & 0.89 & 0.48 & 0.29 & 0.39 & 0.37 & 0.19 & 1.62 & 3.21 \\
\hline Sul & 40 & 35.2 & 37.7 & 37.6 & 4.86 & 17.35 & 15.2 & 8.8 & 6.7 & 7.8 & 7.7 & 2.1 & 0.0 & 64.6 \\
\hline Mean & 2.23 & 1.96 & 2.09 & 2.08 & 0.27 & 0.96 & 0.84 & 0.49 & 0.37 & 0.43 & 0.43 & 0.11 & 0.42 & 3.59 \\
\hline
\end{tabular}

(G) $=$ Genotypes; $(\mathbf{Y p})=$ Grain yield (tonfed-1) under optimal irrigation100\%ETo; $(\mathrm{Ys})=$ Grain yield (tonfed-1) under deficit irrigation 60\%ETo; (MP) = Mean Productivity; $($ GMP $)=$ Geometric Mean Productivity; $($ TOL $)=$ Stress Tolerance; $($ SSI $)=$ Stress Susceptibility Index and = (STI) Stress Tolerance Index.

Regarding TOL index, the higher value of this index referrers to more sensitive genotypes to drought stress. Zangi, (2005) indicated that the low value of Ys or high value of $\mathrm{Yp}$ leads to an increase in TOL value, therefore, genotypes with high TOL have higher sensitivity to drought stress. So, genotypes with lower value of TOL are favored for selection. Results in Table 9 show that Line 2 and Line 6 in 1st season gave lower values of TOL, 
which comprised 0.02 and 0.00 in 1st and 2nd seasons, respectively. So, such lines could be recognized as the best genotypes based TOL index. Nevertheless, Sio-Semardeh et al., (2006) and Dorostkar et al., 2014 TOL failed to recognize the best genotypes, because this parameter would tend to select for low-yielding genotypes which, consequently, means that TOL by itself is not a good index to screen drought tolerant genotypes.

Genotypes with low SSI values were considered as stress tolerant, because such genotypes showed a lower reduction in grain yield under drought stress compared to non-stress condition. SSI has been widely used by researchers to identify sensitive and resistant genotypes (Winter et al., 1988). In this concern, Guttieri et al., (2001) indicated that SSI $>1$ refers to above-average susceptibility, while SSI $<1$ indicates below-average susceptibility to drought stress. In respect in the current study, the lowest value of SSI belonged to line 2 and line 6 the 1st season and 2nd season respectively, whereas genotype 7 and line 9 had the highest SSI in 1st season and 2nd season respectively (Table 9). SSI appeared to be a suitable selection index to distinguish drought -resistant genotypes. STI was more useful index to select the proper cultivars under drought stress and full irrigation conditions as stated by Moghaddam and Hadizadeh (2002). Genotypes had high values of STI showed high MP and GMP indices but lower values of SSI and TOL. Results in Table 9 show that line 5 had the highest value for STI, MP and GMP being 1.02, 2.53, and 2.53 , respectively in the 1st season and comparable values in 2nd season were $4.25,0.51$ and 0.51 , respectively. It's interesting that genotypes 5 surpassed in performance to water deficit conditions the commercials cultivars Sids-6, Shandweel-1, Sahel-1 Sakha93 and Sids-1.

\section{4-Water relationships \\ Applied irrigation water (AW) and water consumptive use (WCU)}

Data in Table 10 illustrated that the highest values of seasonal water applied were observed at mid-season growth stage, and amounted to 61.5 and $63.9 \%$ out of total applied water, respectively, under full and deficit irrigation regimes. Such growing stage is matching higher crop water requirement due to higher growth rate and higher evaporative demands as well. The maximum crop water need is reached at the end of the crop development stage which is the beginning of the mid-season stage that extended to the beginning of late-season stage (FAO, Irrigation Water Management, Training manual No. 3, 1986).

Applied irrigation water, regardless the assessed wheat genotypes, under non-stressed treatment was averaged higher value e.g. $2722 \mathrm{~m} 3 \mathrm{fed}-1$, compared with stressed one $1634 \mathrm{~m} 3 \mathrm{fed}-1$ (Table 10). In this respect, Sallam (2014) studied the effect of DI and RDI (Regular Deficit Irrigation) techniques on the productivity of wheat crop in sandy soils, and found that the amounts of applied water (based on class A pan records) were 6534 and 5151 $\mathrm{m} 3$ ha with full and $75 \%$ ETc irrigation regimes, respectively. Likely, the present data indicate that WCU values exhibited similar trend, where higher average figures e.g. $2042 \mathrm{~m} 3$ fed-1 was attained with full irrigation, whereas with deficit irrigation the value was reduced and being $1225 \mathrm{~m} 3 \mathrm{fed}-1$. In this sense, Bukhat (2005) stated that, exposing wheat crop to water stress depresses seasonal consumptive use.

Table 10. Applied water and water consumptive use under full and deficit irrigation at different wheat growth stages during both growing seasons

\begin{tabular}{|c|c|c|c|c|c|c|c|c|c|c|c|c|}
\hline \multirow{3}{*}{ Growth stages } & \multicolumn{6}{|c|}{ AW (m3fed-1) } & \multicolumn{6}{|c|}{ WCU (m3fed-1) } \\
\hline & \multicolumn{2}{|c|}{ 1st season } & \multicolumn{2}{|c|}{ 2nd season } & \multicolumn{2}{|c|}{ Average } & \multicolumn{2}{|c|}{ 1st season } & \multicolumn{2}{|c|}{ 2nd season } & \multicolumn{2}{|c|}{ Average } \\
\hline & FI & DI & FI & DI & FI & DI & FI & DI & FI & DI & FI & DI \\
\hline Initial & 130 & 78 & 99 & 59 & 114 & 69 & 97 & 58 & 74 & 44 & 86 & 51 \\
\hline Development & 247 & 148 & 233 & 140 & 240 & 144 & 186 & 111 & 175 & 105 & 180 & 108 \\
\hline Mid-season & 1583 & 950 & 1763 & 1058 & 1673 & 1004 & 1187 & 712 & 1322 & 793 & 1255 & 753 \\
\hline Late-season & 721 & 432 & 670 & 402 & 695 & 417 & 540 & 324 & 502 & 301 & 521 & 313 \\
\hline Total & 2681 & 1608 & 2765 & 1759 & 2722 & 1634 & 2010 & 1206 & 2073 & 1243 & 2042 & 1225 \\
\hline
\end{tabular}

(FI) full irrigation (100\%ETO); (DI) deficit irrigation (60\%ETo); (AW) Applied irrigation water (m3fed-1) and (WCU) Water consumptive use (m3fed-1)

\section{Water productivity and water use efficiency}

Data in Table 11 show that both Water Productivity (WP) and Water Use Efficiency (WUE) had the same trend, and being higher for deficit irrigation. Deficit Irrigation averaged 46.99 and 27.78\% higher than Full Irrigation, respectively, in 1st and 2nd seasons. Likely, WUE exhibited higher values with DI, which reached to 45.95 and $25.00 \%$ in 1 st and 2nd higher than those with FI, respectively. Higher WUE values under DI were previously reported by Zhang et al., (2005) who reported that wheat grown under the Regular DI had 26\% greater WUE compared with the control. In addition, Wang et al. (2012) found low irrigation treatment had a higher WUE than that with high irrigation over the 2 years.

Based on the average over the tested genotypes, it is notable that WP under FI and DI in 1st season were higher by 361.11 and $430.43 \%$ than those in 2 nd season, respectively. In addition, WUE exhibited the same trend, where the values under FI and DI in 1st season exceeded those in 2nd season by 362.5 and $4400 \%$, respectively. The highest WP and WUE in 1st season compared with 2 nd season are attributable to the drastic reduction in grain yield in 2nd season, whereas WCU did not greatly differ.

Water Consumptive Use Efficiency (ECU\%)

Data in Table 12 indicate that water consumptive use efficiency $\%$ under full and deficit irrigation at different wheat growth stages and seasonally did not greatly alter due to the adopted irrigation treatments, and the obtained values ranged between 74.2 and $76.9 \%$ in 1st and 2nd seasons. It clear that not less than $24 \%$ of applied irrigation is lost, however, decreasing the losses of applied water could be achieved through reducing runoff and percolation losses due to over-irrigation. Furthermore, avoiding midday sprinkling to reduce direct evaporation and 
avoiding excessive cultivation to reduce deep water percolation and proper planting time as well are advisable practices to accomplish efficient water use.

Table 11. Water Productivity (WP) and Water Use Efficiency (WUE) as affected by FI and DI in the two growing seasons WP (kgm3fed-1) WUE (kg m3fed-1)

\begin{tabular}{lcccccccc} 
& \multicolumn{4}{c}{ WP (kgm3fed-1) } & \multicolumn{4}{c}{ WUE (kg m3fed-1) } \\
\cline { 2 - 9 } Genotypes & \multicolumn{1}{c}{ 1st season } & 2nd season & \multicolumn{3}{c}{ 1st season } & 2nd season \\
\cline { 2 - 9 } & FI & DI & FI & DI & FI & DI & FI & DI \\
\hline Line1 & 0.77 & 1.22 & 0.16 & 0.25 & 1.03 & 1.63 & 0.22 & 0.33 \\
Line 2 & 0.79 & 1.31 & 0.17 & 0.23 & 1.05 & 1.74 & 0.22 & 0.31 \\
Line 3 & 0.71 & 1.14 & 0.16 & 0.24 & 0.95 & 1.53 & 0.22 & 0.31 \\
Line 4 & 0.91 & 1.14 & 0.20 & 0.24 & 1.21 & 1.52 & 0.27 & 0.32 \\
Line 5 & 0.98 & 1.52 & 0.20 & 0.28 & 1.30 & 2.02 & 0.27 & 0.37 \\
Line 6 & 0.70 & 0.96 & 0.13 & 0.22 & 0.93 & 1.28 & 0.18 & 0.30 \\
Line 7 & 0.96 & 1.12 & 0.17 & 0.22 & 1.28 & 1.49 & 0.22 & 0.30 \\
Line 8 & 0.84 & 1.11 & 0.20 & 0.25 & 1.11 & 1.48 & 0.27 & 0.33 \\
Line 9 & 0.80 & 1.32 & 0.20 & 0.16 & 1.07 & 1.76 & 0.27 & 0.22 \\
Line10 & 0.78 & 1.25 & 0.18 & 0.29 & 1.04 & 1.67 & 0.25 & 0.39 \\
Line 11 & 0.91 & 1.48 & 0.22 & 0.25 & 1.21 & 1.97 & 0.29 & 0.33 \\
Line 12 & 0.90 & 1.42 & 0.18 & 0.20 & 1.20 & 1.90 & 0.25 & 0.27 \\
Line 13 & 1.03 & 1.32 & 0.17 & 0.24 & 1.37 & 1.76 & 0.23 & 0.31 \\
Sids-6 & 0.90 & 1.22 & 0.17 & 0.17 & 1.19 & 1.63 & 0.22 & 0.23 \\
Shandaweel-1 & 0.81 & 1.04 & 0.15 & 0.22 & 1.08 & 1.39 & 0.20 & 0.30 \\
Sahel-1 & 0.65 & 0.96 & 0.15 & 0.21 & 0.86 & 1.28 & 0.20 & 0.28 \\
Sakha 93 & 0.68 & 1.08 & 0.18 & 0.21 & 0.91 & 1.43 & 0.24 & 0.28 \\
Sids-1 & 0.85 & 1.31 & 0.17 & 0.17 & 1.14 & 1.74 & 0.23 & 0.23 \\
Average & 0.83 & 1.22 & 0.18 & 0.23 & 1.11 & 1.62 & 0.24 & 0.30 \\
\hline
\end{tabular}

Table 12. Water consumptive use efficiency $\%$ under full and deficit irrigation at different wheat growth stages and seasonally during both growing seasons

\begin{tabular}{lcccc}
\hline \multirow{2}{*}{ Growth stage } & \multicolumn{2}{c}{ 1st season } & \multicolumn{2}{c}{ 2nd season } \\
\cline { 2 - 5 } & FI & DI & FI & DI \\
\hline Initial & 76.9 & 74.4 & 74.7 & 74.6 \\
Development & 75.3 & 75.0 & 75.1 & 75.0 \\
Mid-season & 75.0 & 74.9 & 74.9 & 74.9 \\
Late-season & 74.9 & 75.0 & 74.9 & 74.9 \\
Total & 74.2 & 75.0 & 75.0 & 74.9 \\
\hline
\end{tabular}

\section{REFERENCES}

Ahmadzadeh, A. 1990. Determining the best indices of drought stress in selected maize lines. M.Sc. Thesis, Tehran University, Iran.

Ahmed, M., M.A. Arain and K.A. Siddiqui. 1994. Effect of contemporary rotation simulation on the grain weight, protein and lysine content of bread wheat (Triticum aestivum L.). Pak. J. of Bot. 26(2): 311- 339.

Ali, M.H., Hoque, M.R., Hassan, A.A., Khair, A. 2007. Effects of deficit irrigation on yield, water productivity and economic returns of wheat. Agric. Water Manage. 92 (3): 151-161.

Almeselmani, M., AL-Rzak Saud, A., Al-Zubi, K., ALGhazali, S., Hareri, F., AL-Nassan, M., Ammar, M.A., Kanbar, O.Z., AL-Naseef, H., AL-Nator, A., AL-Gazawy, A. and Teixeira da Silva, J.A. 2015. Evaluation of physiological traits, yield and yield components at two growth stages in 10 durum wheat lines grown under rainfed conditions in southern Syria. Cercetări Agronomice in Moldova. 2, 162: 29-49.

Bukhat N.M. 2005. Studies in yield and yield associated traits of wheat (Triticum aestivum L.) genotypes under drought conditions. MSc Thesis. Department of Agronomy. Sindh Agriculture University, Tandojam, Pakistan.
Doornbos, J., Pruit, W.O. 1975. Crop Water Requirements. Irrigation and Drainage Paper, No. 24. FAO, Rome.

Dorostkar, S., A. Dadkhodaie and B. Heidari. 2014. Evaluation of grain yield indices in hexaploid wheat genotypes in response to drought stress. Archives Agro. And Soil Sci., 61:397-413.

Esmail, R.M., Sara E.I. Eldessouky, Sherin A. Mahfouze and I.S. EL-Demardash. 2016. Evaluation of new bread wheat lines (Triticum aestivum L.) under normal and water stress conditions. International Journal of ChemTech Research. 9, (5):89-99.

FAO, 1984. Crop water requirements. Irrigation and Drainage paper no. 24, FAO, Rom, Italy.144p.

Fernandez G.C.J. 1992. Effective selection criteria for assessing stress tolerance. In: Kuo, C.G. (Ed.) Proceedings of the International Symposium on Adaptation of Vegetables and Other Food Crops in Temperature and Water Stress. Tainan, Taiwan.

Fischer, R.A., Maurer, R. 1978. Drought resistance in spring wheat cultivars. I. Grain yield responses. Crop and Pasture Science 29:897-912.

Gomez, K.A., Gomez, A.A. 1984. Statistical Procedures for Agricultural Research, second ed. Willey and Sone Inc., New York, USA.

Gupta, N. K., Gupta, S., Kumar, A. 2001. Effect of water stress on physiological attributes and their relationship with growth and yield in wheat cultivars at different growth stages. Journal of Agronomy. No. 86 p. 1437-1439.

Guttieri, M.J., J.C. Stark, K. Brien and E. Souza. 2001. Relative sensitivity of spring wheat grain yield and quality parameters to moisture deficit. Crop Sci., 41:327-335.

Haikel, M.A. and El-Melegy, A.M. 2005. Effect of irrigation requirements, seeding rates and bio mineral fertilizer on wheat productivity in newly reclaimed soil under sprinkler irrigation system. J. Productivity and development, 10(1):113-134.

Hamed, H.C.M, M. Rezig and M.B. Naceur. 2015. Water Use Efficiency of Durum Wheat (Triticum durum Desf) under Deficit Irrigation. Journal of Agricultural Science Vol. 7, No. 8: 238- 249.

Hossain, A.B.S., R.G. Sears, T.S. Cox and G.M. Paulsen. 1990. Desiccation tolerance and its relationship to assimilate partitioning in winter wheat. Crop Sci., 30:622-627.

James, L.G., 1988. Principles of Farm Irrigation System Design. John Willey and Sons Inc., New York, USA, 543p.

Mandal, K.G., K.M. Hati, A.K. Misra; K.K.Bandyopadhyay and Mohanty, M. 2005. Irrigation and nutrient effects on growth and wateryield relationship of wheat (Triticum aestivum L.) in Central India. J. Agron Crop Sci. 191: 416 - 425.

Mark, T. and B. Antony. 2005. Abiotic stress tolerance in grasses from model plants to crop plants. Plant Physiol. 137: 79 1-793.

Menshawey, A.M.M., A.A. E-Hag and Soaad El-Sayed, A. 2006. Evaluation of some agronomic and quality traits for some wheat cultivars under different irrigation treatments. The First Field Crops Res. Ins. Conference, 22-24 Aug., Giza, Egypt, 294-310. 
Moghaddam, A. and Hadizadeh, M.H. 2002. Response of corn (Zea mays L.) hybrids and their parental lines to drought using different stress tolerance indices. Seed Plant, 18(3): 255-272.

Nazari, L. and H. Pakinyat. 2010. Assessment of drought tolerance in barely genotypes. J. Appl. Sci., 10:151-156.

Pireivatlou, A.S; Masjedlou, B.D; Aliyev, R.T. 2010. Evaluation of yield potential and stress adaptive trait in wheat genotypes under post anthesis drought stress conditions, Afric J of Agric Res. 5: 2829-2836.

Rajaram, S., M. van Ginkel, and R.A. Fischer. 1994. CIMMYT's wheat breeding mega- environments (ME). p. 1101-1106. In Proc. Intl. Wheat Genet. Symp., 8th, Beijing, China. 1-6 Sept. 2003. Agric. Scientech Press, Beijing, China.

Saini, H.S. and Aspinal L., D. 1981. Effect of water deficit on sporgenesis in wheat (Triticum aestivum L.), Ann. Bot. 48:623- 6S3.

Sallam, A.A. 2014. Response of wheat crop to the amount and the quality of irrigation water in calcareous soils, under surface and sprinkler irrigation systems. $\mathrm{PhD}$ Thesis, Faculty of Agriculture, Moshtohor, Benha Universit y, Egypt.

Shirazi, A., Bahiraee, A., Ahmadi, E., Nazari, H., Heidari, B., Borjian, S. 2009. The Effect of the duration of in vitro maturation (IVM) on parthenogenetic development of ovine oocytes. American Journal of Molecular Biology 1: 181-191.

Shpiler, L. and Blum, A. 1991. Heat tolerance toyield and its components in different wheat cultivars. Euphytica 51:257-263.

Singh, R.B., C.P.S. Chauhna and Minhas, P.S. 2009. Water production functions of wheat irrigation with saline and alkali waters using double line source sprinkler system Agric. Water Management, 96(5):736-744.

Singh, T. and G.S. Dhaliwal. 2000. Performance of wheat varieties under late sowing conditions in southwestern region of Punjab. J. of Res.; Pb. Agri. Univ. 37(3-4):181-183.

Sio-Semardeh, A., A. Ahmadi, K. Postini., V. Mohammadi. 2006. Evaluation of drought resistance indices under various environmental conditions. Field Crop Res. 98:222-229.
Smith, A. D. 1991. National Identity. London: Penguin.

Talebi, R., F. Fayaz and Naji, A.M. 2009. Effective selection criteria for assessing drought stress tolerance in durum wheat (Triticum durum Desf.), General and Applied Plant Phys., 35: 64-74.

Tawfelis, M.B. 2006. Stability parameters of some bread wheat genotypes (Triticum aestivum L.) in new and old lands under Upper Egypt, Egypt. J. Plant Breed, 10 (1): 223-246.

Waller, R.A. and Duncan, D.B. 1969. A Bayes Rule for the Symmetric Multiple Comparison Problem, Journal of the American Statistical Association 64, pages 1484-1504.

Wang, F., C. Kummerow, A.J. Geer, P. Bauer, and G. Elsaesser, 2012. Comparing rain retrievals from GPROF with ECMWF 1D-Var products. Q. J. Roy. Meteorol. Soc., 138, no. 568:1852-1886.

Winter, S.R., J.T. Musick and K.B. Porter. 1988. Evaluation of screening techniques for breeding drought-resistant winter wheat. Crop Sci., 28:512516.

Zafarnaderi, N., S. Aharizad and Mohammadi, S.A. 2013. Relationship between grain yield and related agronomic traits in bread wheat recombinant inbred lines under water deficit condition. Annals of Bio. Res., 4(4):7-11.

Zangi, M.R. 2005. Correlation between drought resistance indices and cotton yield in stress and non-stress conditions. Asian J. of Plant Sci., 4: 106-108.

Zareian, A., Abad H.H.S and Hamidi, A. 2014.Yield, yield components and some physiological traits of three wheat (Triticum aestivum L.) cultivars under drought stress and potassium foliar application treatments. Int. J. of Biosciences. 4, (5):168-175.

Zhang, X.; Chen, S.; Liu, M.; Pei, D.; Sun, H. 2005. Improved water use efficiency associated with cultivars and agronomic management in the North China Plain. Agronomy Journal 97, 783-790.

Zhong-hu, H., Rajaram, S. 1994. Differential responses of bread wheat characters to high temperature. Euphytica 72:197-203.

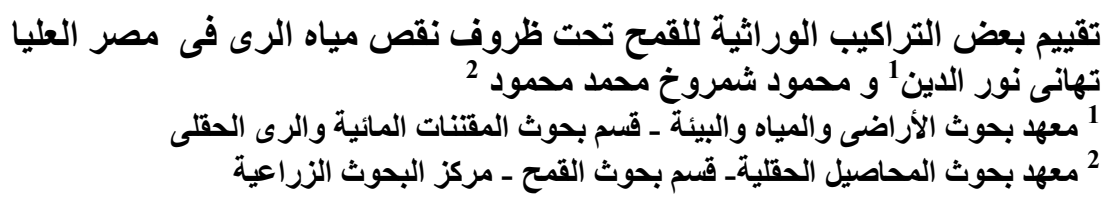

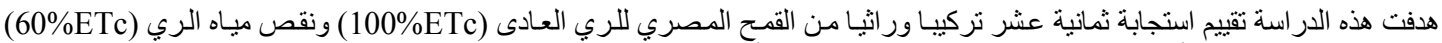

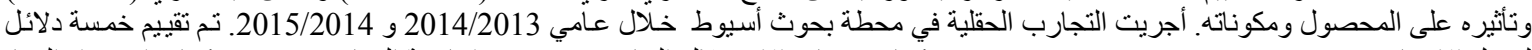

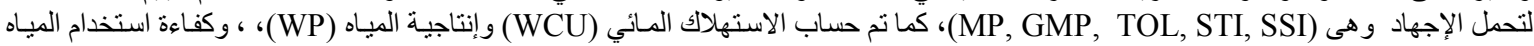

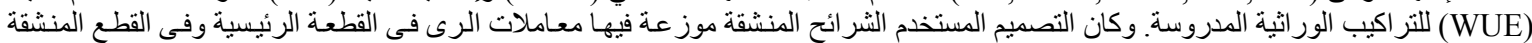

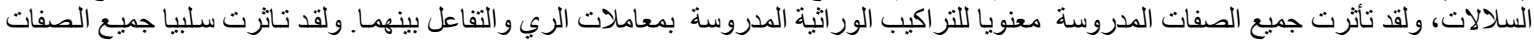

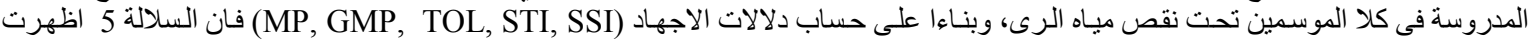

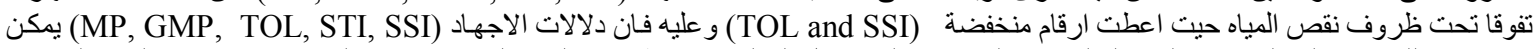

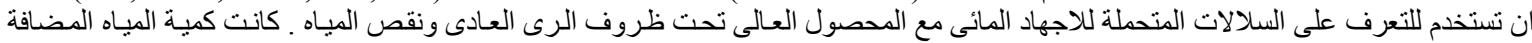

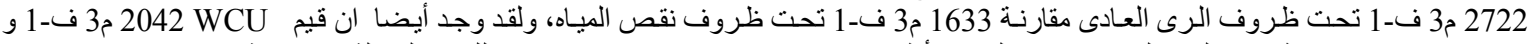

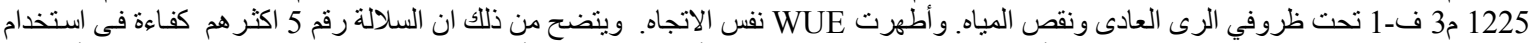

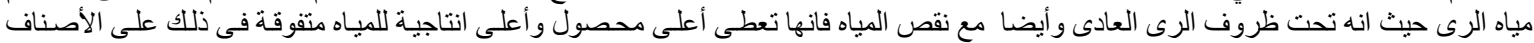

